\title{
The hierarchization of needs related to land consolidation and exchange in rural areas in the villages of district Leżajsk
}

\author{
Justyna Wójcik-Leń ${ }^{1}$ and Przemystaw Len $^{1, *}$ \\ ${ }^{1}$ Department of Environmental Engineering and Geodesy, University of Life Sciences, Poland
}

\begin{abstract}
Rural areas in Poland are characterized by differentiated spatial structure. The spatial structure of rural areas can be improved through the consolidation and exchange of land (Art.1, Act of 26 March 1982 on consolidation and exchange of land) aiming to create more favourable management conditions in agriculture and forestry by improving the territorial structure of farms, forests and forestland, reasonable configuration of land, aligning the limits of real properties with the system of water irrigation facilities, roads and terrain. In connection with such a requirement for the consolidation and exchange of land, a hierarchy of needs and their urgency must be established. Such an approach makes it possible to secure funds for liquidating the spatial structure of agricultural land according to the urgency ranking. The studies were carried out in the rural areas of the Leżajsk poviat.
\end{abstract}

\section{Introduction}

The policy of the European Union up until 2020 to be pursued in rural areas is oriented at diversifying the functions performed by rural land. In EU member states, including Poland, the spatial structure of rural areas is the land consolidation process. The basic definition and purpose of consolidation is given in the Act of 26 March 1982 on consolidation and exchange of land (JL) of 2013, item 1157), where consolidation was defined as the "rural management procedure aiming at transformation of the spatial arrangement of rural land in order to create more favourable management conditions by improving the territorial structure of farms, reasonable configuration of land, and aligning the limits of real properties with the system of water irrigation structures, roads and terrain".

The Rural Development Programme for the years 2014-2020 promulgates land consolidation works as geodesic procedures in which "new plots are formed in a configuration different from that of original plots in order to reduce the number of small, scattered plots constituting a single farm and to increase their average size. The consolidation project also includes works related to post-consolidation management of land, that is, in particular, creating a functional system of access roads to agricultural land and forestland and performing tasks affecting the regulation of the water regime in the consolidated area".

The combination of the above-mentioned definitions and six priorities of the RDP for 2014-2020 in performing consolidation works will make it possible to follow a multi-functional and sustainable development scheme combining the conditions of management and elements of the environment and landscape [1-3]. Land consolidation should be given comprehensive treatment as a process under which multidirectional activities are carried not only to improve the agrarian structure of farms but also to implement the concept of multifunctional development of rural areas. The abovementioned activities include works related to improving the status of water management within the object of consolidation [4].

The most common defects of the spatial structure of private agricultural land in Poland are: the small area of plots, large number of plots constituting the farm, and small plot area in particular in the territory with differentiated terrain relief $[5,8]$. This is mainly the case in southern and south-eastern Poland [9-11]. Land in the eastern and central regions of Poland is characterized by considerable defectiveness as the plots in the lowlands are very narrow and significantly elongated. In addition, the plots are unshapely and have no access roads and, most importantly, the land is scattered in and outside the limits of the village [12-16]. Such a state of affairs has a negative effect on building a full-featured real property cadastre [17-25].

Works converting the unfavourable arrangement of land within the entire area cannot be undertaken for technical and financial reasons. Therefore, land consolidation and exchange works should be undertaken only in villages having the most urgent needs. Thus, it is necessary to evaluate the degree of defectiveness of the spatial structure of land in order to determine the requirement of land consolidation and exchange works, and most of all - their sequence. Two independent statistical methods were used for the purposes of the survey: Hellwig's development measure and zero unitarization method, which made it possible to create

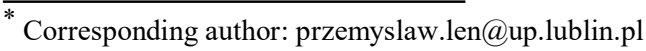


independent rankings for hierarchization of land consolidation and exchange works.

\section{Identification of the urgency of land consolidation works in the villages of the Leżajsk poviat}

The application of statistical methods in scientific research was widely discussed by $[26,27]$. Developing a ranking of objects taking into account the set of their characteristic features is a fundamental task of statistical analyses. Normally, diagnostic variables have different labels and different ranges of variation, which prevents comparing them directly and adding them. In order to compare diagnostic features, one needs to make them uniform in size and deprive them of labels. An unquestionable advantage of some techniques is obtaining variables contained within the range [0,1]. This process is called the feature normalization method. Next, the values of diagnostic features are aggregated. Finally, one comes up with synthetic features which describe respective villages in terms of the adopted study objective and form grounds for developing a ranking which classifies villages from the worst to the best synthetic value [28]. In order to determine the sequence and urgency of land consolidation and exchange works in the analyzed area, 19 characteristic features of all villages in the Leżajsk poviat were adopted: $\mathrm{x} 1$ - total area [ha], x2 - total number of plots, x3 - number of residents, $x 4$ - number of residents per $1 \mathrm{~km} 2, x 5-\%$ of area of land from group 7, x6 - \% of the number of plots from group 7, x7 - average plot area, $\mathrm{x} 8-\%$ of plots in subgroup 7.1, x9 - \% of the number of plots in subgroup 7.1 in relation to group $7, \mathrm{x} 10-\%$ of the area of plots in relation to group $7, \mathrm{x} 11$ - average number of plots per registration unit, $\mathrm{x} 12$ - average area of a registration unit, x13 - cropland, x14 - grassland, x15 - \% of land owned by the agricultural property agency of the state treasury, group $1.1, \mathrm{x} 16-\%$ of the land owned by gminas, x17 $\%$ of orchards, x18 - \% of forests, x19 - fragmentation ratio.

Hellwig's development measure synthesizes information from the sequence of diagnostic variables and assigns a single aggregated measure to the analyzed phenomenon [29].

The algorithm illustrating the sequence of calculation in Hellwig's method is as follows:

a) based on arrays of standardized input data a model object with standardized coordinates is designated:

$$
\begin{gathered}
\mathbf{O}_{0}=\left\lfloor z_{o j}\right\rfloor \\
j=1,2, \ldots \mathrm{n}
\end{gathered}
$$

b) the coordinates of the model object are calculated according to the following formula:

$$
z_{o j}=\max _{i}\left\{z_{i j}\right\}
$$

when the selected feature is an LTB (larger-the-better) characteristic

$$
z_{o j}=\min _{i}\left\{z_{i j}\right\}
$$

when the selected feature is an STB (smaller-the-better) characteristic $\mathrm{j}=1,2, \ldots, \mathrm{m}$.

c) next, for each object the distance from the model object is calculated, most often by applying the Euclidean metric:

$$
\begin{gathered}
d_{i 0}=\left[\sum_{j=1}^{m}\left(z_{i j}-z_{0 j}\right)^{2}\right]^{\frac{1}{2}} \\
\mathrm{i}=1,2, \ldots, \mathrm{n} .
\end{gathered}
$$

d) the synthetic measure is defined as:

$$
s_{i}=1-\frac{d_{i 0}}{d_{0}} \quad \mathrm{i}=1,2, \ldots, \mathrm{n},
$$

where:

$$
d_{0}=\bar{d}_{0}+2 S\left(d_{0}\right)
$$

whereas:

$$
\begin{gathered}
\bar{d}_{0}=\frac{1}{n} \sum_{i=1}^{n} d_{i 0} \\
S\left(d_{0}\right)=\left[\frac{1}{n} \sum_{i=1}^{n}\left(d_{i 0}-\bar{d}_{0}\right)^{2}\right]^{\frac{1}{2}}
\end{gathered}
$$

Measure si normally assumes values in the range $[0,1]$. The values are higher when the specific object is closer to the model. The above-presented statistical method was used in order to create a ranking of urgency of undertaking land consolidation works and its results were compared with results obtained by means of the zero unitarization method used by the author in previous studies.

The zero unitarization method makes it possible to standardize diagnostic variables describing the analyzed object. These variables can be split into the following groups [30]:

1) LTB (larger-the-better) - variables whose increased value contributes to higher evaluation of a characteristic of the analyzed object; then, standardized variables are calculated according to the formula:

$$
Z=\frac{\left(x-x_{\min }\right)}{\left(x_{\max }-x_{\min }\right)}
$$

2) STB (smaller-the-better) - variables whose increased value contributes to lower evaluation of a characteristic of the analyzed object; then, standardized variables are calculated according to the formula:

$$
Z=\frac{\left(x_{\max }-x\right)}{\left(x_{\max }-x_{\min }\right)}
$$

where: 
$\mathrm{z}$ - standardized variable,

$\mathrm{x}$ - non-standardized variable,

$\mathrm{xmax}-$ maximum value of the variable in a specific set, xmin - minimum value of the variable in a specific set.

Standardization of diagnostic features facilitates an overall multi-criterion evaluation of every object. The total evaluation is achieved by aggregation. In order to obtain a synthetic measure mean values are calculated for sets describing the respective features according to the following formula [28]:

$$
\begin{gathered}
z_{i}=\frac{1}{p} \sum_{j=1}^{p} x_{i j} \\
(\mathrm{i}=1, \ldots, \mathrm{n})
\end{gathered}
$$

Standardized measures fall within the range $[0,1]$. The results are interpreted as an average of optimum values achieved by each of the objects. Thus, the higher the position of the object in the created ranking is, the higher the value of the synthetic measure.

\section{Analysis of results}

This paper aims to determine the measure of urgency of land consolidation and exchange using Hellwig's development method (blue line) and compare the results with those obtained for the zero unitarization method (red line). Figure 1 presents the values obtained with regard to urgency of land consolidation and exchange works for respective villages according to the statistical methods used. It was determined that for all 8 villages similar values of urgency measures were obtained for land consolidation and exchange works.

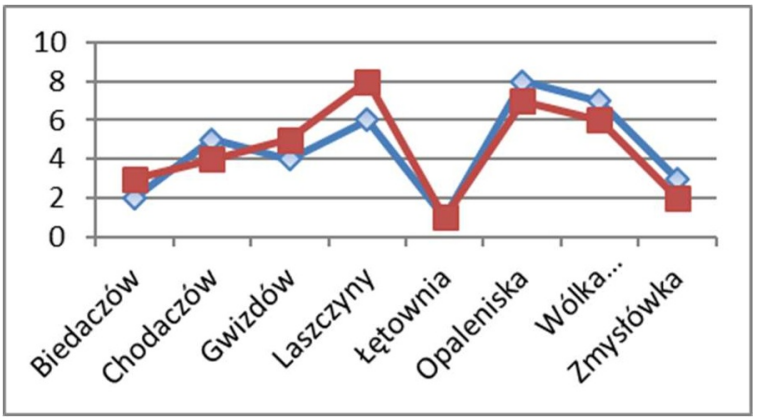

Fig. 1. Position in the ranking according to two statistical methods

Ordering the villages according to the value of determined measures (Table 1,2$)$ it was found that land consolidation works should be undertaken with the highest urgency in the villages of Łętownia, Biedaczów and Zmysłówka.

The least defective spatial structure was recorded in the village of Opaleniska. Łętownia is a village with the largest area and the highest number of plots with the average plot area being 0.44 ha. Plots with an area up to 0.10 ha account for $22.66 \%$ of the total number of plots. If the plots have a larger area, they are considerably elongated, which is very disadvantageous for mechanical cultivation. In Biedaczów the average area of a plot is
0.36 ha. Plots with an area up to 0.10 ha account for $25.97 \%$. Agricultural land is considerably elongated and it often lacks access roads. In the village of Zmysłówka plots with an area up to 0.10 ha account for $21.07 \%$ of the total number of plots. Many plots have irregular boundaries and they often have no access to the road. Opaleniska is the village with the smallest area. The average area of a plot is 0.40 ha. Predominant soil class in cropland is class V and VI. In total, they account for $89.02 \%$ of the total area of cropland.

Table 1. Ranking of urgency of land consolidation works using Hellwig's development measure.

\begin{tabular}{|c|c|c|}
\hline $\begin{array}{c}\text { Ranking } \\
\text { position }\end{array}$ & $\begin{array}{c}\text { Hellwig's } \\
\text { development } \\
\text { measure }\end{array}$ & Village \\
\hline 1 & 0.985 & Łętownia \\
\hline 2 & 0.436 & Biedaczów \\
\hline 3 & 0.409 & Zmysłówka \\
\hline 4 & 0.381 & Gwizdów \\
\hline 5 & 0.365 & Chodaczów \\
\hline 6 & 0.334 & Laszczyny \\
\hline 7 & 0.312 & Wólka Lętowska \\
\hline 8 & 0.241 & Opaleniska \\
\hline
\end{tabular}

Table 2. Ranking of urgency of land consolidation works zero unitarization method

\begin{tabular}{|c|c|c|}
\hline $\begin{array}{c}\text { Ranking } \\
\text { position }\end{array}$ & $\begin{array}{c}\text { Zero } \\
\text { unitarization } \\
\text { method }\end{array}$ & Village \\
\hline 1 & 0.584 & Łętownia \\
\hline 2 & 0.538 & Zmysłówka \\
\hline 3 & 0.522 & Biedaczów \\
\hline 4 & 0.522 & Chodaczów \\
\hline 5 & 0.5 & Gwizdów \\
\hline 6 & 0.482 & Wólka Łętowska \\
\hline 7 & 0.429 & Opaleniska \\
\hline 8 & 0.258 & Laszczyny \\
\hline
\end{tabular}

\section{Conclusions}

The Leżajsk poviat is one of a few poviats in the Subcarpathian voivodeship where the highest number of land consolidation works was performed. Consolidation started right after World War II and has continued to this day. So far consolidation has been completed in 29 precincts covering a total area of 46113 ha, which accounts for $79 \%$ of the total area of the poviat. Consolidation must still be performed in 8 precincts rural areas totalling 6605 ha, which accounts for $11.32 \%$ of the total area of the poviat. The created rankings of urgency of land consolidation works in selected villages of the Leżajsk poviat facilitate identifying villages characterized by the highest defectiveness of spatial 
structure that can be eliminated in the process of land consolidation and exchange.

Defective spatial structure of farms is a very serious obstacle to modernizing agricultural production in order to adapt it to the changing market conditions. In addition, the size of agricultural plots often smaller than 0.10 ha excludes the possibility of obtaining financial support in the form of direct payments to farmers and the width of plots precludes their forestation. At present, land consolidation works have measurable effects:

- the consolidation procedure is $100 \%$ financed from public funds at no cost for the participants of consolidation,

- new lots are demarcated, new plot boundaries are defined and permanent boundary markers are used,

- the number of plots is reduced, and thus, the average area of the plots increases,

- the distance between the plots and the owner's dwelling is reduced, which shortens the time of access and reduces the cost of agricultural production,

- each plot after consolidation has access to an internal or a public road,

- the number of irregularly shaped plots is reduced to the necessary minimum,

- the boundaries of the plots are aligned with the system of water irrigation structures, roads and terrain,

- agricultural tax exemptions and credits for three years,

- a functional network of roads is demarcated and developed, including roads leading to agricultural land and forestland and roads to farm buildings; the technical parameters of such roads match currently used farming machinery,

- the routing of land improvement facilities is adjusted and their technical parameters are improved,

- redundant balks and roads are removed and reclamation works allowing mechanical cultivation of plots are undertaken,

- the territorial structure of farms is improved by increasing their area with the land of farmers intending to give up agricultural production, in exchange for direct cash payments,

- the structure of cropland can be adjusted and soils can be differentiated according to the needs of the production direction selected by the farm,

- the boundaries of residential plots can be adjusted if necessary,

- properly situated land can be allocated housing needs,

- unnecessary land easement can be abolished,

- necessary land can be allocated for local public utility purposes,

- joint ownership of agricultural real property can be abolished free of charge at the request of all joint owners,
- common land can be split free of charge upon the approval of an absolute majority of people authorized to a share of the common land,

- cadastral documentation is developed for the consolidated precincts in compliance with the requirements of currently applicable technical standards,

- land surveying and legal documentation necessary to record the post-consolidation status in land and mortgage registers is developed.

\section{Acknowledgements}

Publication supported by the Polish Ministry of Science and Higher Education as a part of the program of activities disseminating science from the project „Organization of the First International Science Conference - Ecological and Environmental Engineering”, 26-29 June 2018, Kraków.

\section{References}

1. K. Sobolewska-Mikulska, J. Wójcik, Acta Scientiarum Polonorum. Geodesia et Descriptio Terrarum. Vol. 11 (4), 27-38, (2012).

2. J. Wójcik, Infrastruktura i Ekologia Terenów Wiejskich, 2012/01, 79-91(2012).

3. K. Sobolewska-Mikulska, M. Stańczuk-Gałwiaczek, Journal of Agribusiness and Rural Development, 1 (47), 81-88, (2018).

4. M. Stańczuk-Gałwiaczek M. 2016. WodaŚrodowisko-Obszary Wiejskie, 16, (53), 55-69, (2016).

5. K. Noga, Metodyka programowania i realizacji prac scalenia $i$ wymiany gruntów $w$ ujęciu kompleksowym. Akademia Rolnicza im. H. Kołłątaja w Krakowie, Kraków (2001).

6. J. Wójcik-Leń, K. Sobolewska-Mikulska, Journal of Water and Land Development, 34, 249-258, (2017).

7. J. Wójcik-Leń, K. Sobolewska-Mikulska, N. Sajnóg, P. Leń, Land Use Policy 78, 36-45, (2018)

8. J. Wójcik-Leń, P. Leń, K. Sobolewska-Mikulska, Computers and Electronics in Agriculture 152, 333$339,(2018)$

9. J. Gniadek, Infrastruktura i Ekologia Terenów Wiejskich, 2010/01, 151-161, (2010).

10. J. Gniadek, Infrastruktura i Ekologia Terenów Wiejskich, 2011/ 02, 149-159, (2011).

11. J. Wójcik-Leń, Ż. Stręk, Proposal for Land Consolidation Project Solutions for Selected Problem Areas. The World Multidisciplinary Earth Sciences Symposium (WMESS 2017). IOP Conf. Series: Earth and Environmental Science 95, (2017).

12. K. Noga, Ż. Król, Barometr Regionalny. Analizy i Prognozy, 14, 3, 165-173, (2016).

13. Ż. Król, P. Leń, Infrastruktura i Ekologia Terenów Wiejskich, II/1/2016, 317-318, (2016).

14. Z. Strek, Engineering for rural development analysis of demand for land consolidation in Milejów commune, Łęczna district. ENGINEERING FOR RURAL DEVELOPMENT, 593-599, (2017). 
15. E. Jasińska, Land use efficiency on example of the transformation of rural properties. The 10th International Conference Environmental Engineering, (2017).

16. J. Wójcik-Leń, Ż. Stręk, The share of land belonging to non-resident owners in a village intersected by a motorway - case study. Geographic Information Systems Conference and Exhibition, GIS ODYSSEY 2017: Conference proceedings, 427-435, (2017).

17. P. Hanus, Geodesy and Cartography, 62(1), 51-65, (2013).

18. P. Hanus, E. Jasinska, E. Preweda, Analysis of the accuracy of determining the coordinates of property borders. In Environmental Engineering. Proceedings of the International Conference on Environmental Engineering. ICEE (Vol. 9, p. 1). (2013)

19. A. Dawidowicz, R. Źrobek, Analysis of concepts of cadastral system technological development. Procedia Engineering. (presentation at the 9th International Conference "Environmental Engineering" Vilnius Gediminas Technical University, May 22, 2014 - May 23, 2014, (2014).

20. M. Mika. REPORTS ON GEODESY AND GEOINFORMATICS, 102, 1, 67-77. (2016).

21. M. Mika, Acta Scientiarum Polonorum-Formatio Circumiectus, 16, 1, 3-14. (2017).

22. L. Hudecova, P. Nemcova, R. Geisse, M. Bajtala, Renewal of cadastral maps. 16th International Multidisciplinary Scientific GeoConference SGEM
2016, www.sgem.org , SGEM2016 Conference Proceedings, 2, 2, 511-518, (2016)

23. A. Dawidowicz, R. Źróbek, Land Use Policy 73, 59-72. (2018)

24. P. Hanus, A. Pęska-Siwik, R. Szewczyk, Computers and Electronics in Agriculture, 144, 9-15. (2018)

25. E. Jasińska, E. Preweda, The use of regression trees to the analysis of real estate market of housing. SGEM2013: GeoConference on Informatics, geoinformatics and remote sensing. www.sgem.org, SGEM2013 Conference Proceedings, (International Multidisciplinary Scientific GeoConference) SGEM, 503-508. (2013)

26. E. Preweda, The use of decomposition SVD to approximate a Surface. The 10th International Conference Environmental Engineering: selected papers: April 27-28, 2017, Vilnius, Lithuania. (2017)

27. K. Kukuła, Metody ilościowe w badaniach ekonomicznych. Propozycja budowy rankingu obiektów z wykorzystaniem cech ilościowych oraz jakościowych. Katedra Ekonometrii i Statystyki SGGW, Warszawa, 5-16, (2012)

28. A. Krakowiak-Bal, Infrastruktura i Ekologia Terenów Wiejskich, 3/2005. PAN, Kraków, 71-82, (2005)

29. K. Kukuła, Metoda unitaryzacji zerowanej. PWN, Warszawa, (2000)

30. W. Pluta, Wielowymiarowa analiza porównawcza w modelowaniu ekonometrycznym. PWN, Warszawa, (1986) 